\title{
Forum
}

\section{Applying Wasațyah within the Malaysian Religio-Political Context}

\author{
Ahmad El-Muhammady
}

There is a resurgence of interest in the wasatīyah (moderation) approach among contemporary Muslim academics and policymakers, particularly with regards to its application and utility in resolving social challenges. This renewed interest apparently intensified especially due to Samuel Huntington's 1993 "clash of civilizations" thesis in the aftermath of $9 / 11^{1}$ and the emergence of extremism and liberal thinking in the Muslim world. ${ }^{2}$

This short essay argues that the need for wasatiyah in the present-day context is not due to that factor alone; rather, it is a response to the pervasive extremism manifesting itself in various forms, either in the practice of politics, economics, culture, religion, and others. Economic extremism produced exploitation, market manipulation, inequality, and poverty in many countries. In the realm of politics, extremism appears in the form of global domination, authoritarianism, and even democratization projects that ignore the country's socio-political contexts. Such an effort is meaningless to the locals and, at worst, might jeopardize the democratization project itself.

In addition, the rise of modernity and postmodernity has produced unintended consequences. Modern society tends to engage in the endless pursuit of materialism and conspicuous consumerism, both of which devalue spirituality and the religious life. Modern people, therefore, are intellectually sophisticated but suffer from a spiritual-ethical vacuum due to their excessive pursuit of material gain. The "reign of quantity," as Rene Guénon argued, not only rules supreme in the economic and business domains, but also permeates institutions of higher learning. Eventually liberal education does produce ex-

\footnotetext{
Ahmad El-Muhammady lectures on political science and Islamic studies at the Centre for Foundation Studies, International Islamic University Malaysia. He also serves as the panel member of the Royal Malaysia Police's Special Rehabilitation Program for militant detainees in Malaysia. His research interest includes political violence, religious extremism, and counterterrorism. He can be contacted at elmuhammady@gmail.com.
} 
cellent minds in order to meet the market's demands, yet it is an "excellence without a soul," as Harry Lewis argued in his Excellence without A Soul: Does Liberal Education Have a Future? (2006). ${ }^{3}$

Given the present scenario and background, it is not surprising that Alan Greenspan, former chairman of the U.S. Federal Reserve, described this "new era" as "the age of turbulence" 4 and Mohamed ElBaradei, former directorgeneral of International Atomic Energy Agency (IAEA), suggested "the age of deception." Why? Because the sense of balance, justice, and moderation are missing in human life it has been replaced by the "reign of quantity" as Guenon forewarned in the 1940s. Seyyed Hossain Nasr aptly described this phenomenon as a "spiritual crisis" besetting modern humanity as reflected in his works, inter alia, Man and Nature: The Spiritual Crisis in Modern Man (1968) and Islam and Plight of Modern Man (2002). ${ }^{7}$

Therefore, the revival of and return to the wasatiyah paradigm rooted in Islamic tradition is very timely and spiritually refreshing. This attempt seeks to restore the sense of balance, justice, and moderation from the clutches of extremism and paves the way for more stability and meaning in human life. Today, the wasatizyah approach has gained more currency among Muslim academics, leaders, and policymakers. The word wasatityah also is echoed in the capital cities of Europe, the United States, and Asia, and many Muslim governments have attempted to incorporate this approach in their national agendas and state administrations. Malaysia exhibits a deep interest in this concept and has committed its moral and material support to realize this vision in its state policies and public life.

Malaysia is a pluralist nation comprising 30.4 million people with different ethnicities, religions, and cultures. Since becoming independent in 1957, it has achieved a remarkable degree of socio-economic progress. Despite facing a serious communist insurgency (1960-89) and a racial riot on May 13, 1969 , the Southeast Asian country managed to prevent itself from falling into full-blown civil war and put itself back on the path of stability and harmony. The lasting peace and harmony that Malaysia continues to enjoy today did not happen by accident, but is an outcome of a moderate leadership, a viable consociationalist model, and constitutionalism.

Following the consociationalist model, each ethnic group (i.e., Malays, Chinese, Indians, and the indigenous people) agreed to form a grand coalition and govern the country via power-sharing, compromise, and tolerance. The constitution designates Islam as the official religion while allowing other religions to be practiced. The resulting tolerance and reasonable accommodation is a give-and-take situation and is obviously the basis of Malaysia's stability. ${ }^{8}$ One can conclude that modern Malaysia was built upon the principle of mod- 
eration due to the resulting power-sharing principle, peaceful coexistence, and mutual respectability. Unlike other multiethnic countries in the post-colonial period, the country has drawn upon its ethnic diversity as a source of strength instead of conflict.

Prime ministers Mahathir Mohamad (1981-2003), Abdullah Badawi (2003-09), and Najib Tun Abdul Razak (2009- ) have engineered national development plans and strategies to strengthen the country on the basis of its religio-political system. In 1991 Mahathir introduced Vision 2020, which seeks to develop Malaysia into a fully industrialized nation with a balanced development, a fusion of economic progress and a developed human personality. ${ }^{9}$ In essence it was designed to pursue economic development without sacrificing ethics, religious identity, and ethnicity. Mahathir's implementation of Islamic values in his administration is another indicator of inculcating a "moderate" Islam, despite the comments of some observers that its real goal was to placate the Islamist opposition Parti Islam Se-Malaysia (PAS) party. ${ }^{10}$

Badawi's ascendancy to the premiership in 2003 represented another progressive step toward implementating wasatizyah: the introduction of Islam Hadhari (civilizational Islam) initiatives. This concept consists of ten principles, namely, faith and piety in Allah, a just and trustworthy government, freedom and independence to the people, the mastery of knowledge, balanced and comprehensive economic development, a good quality of life for all, protection of the rights of minority groups and women, cultural and moral integrity, protection of the environment, and a strong defense policy. ${ }^{11}$

Badawi envisions Islam Hadhari as an approach that both emphasizes development consistent with the tenets of Islam and focuses on enhancing the quality of life. It can be achieved through mastering knowledge, developing the individual and the nation, implementing a dynamic trading and financial system, and pursuing the integrated and balanced development of people and protecting the weak and disadvantaged. Apart from that, it attempts to "expand the scope of the Islamic discourse to include the broader civilizational teachings and objectives of Islam, thus projecting the values of moderation, social harmony, people's welfare and social development." 12

These initiatives have been translated into various national policies in several areas, among them religious affairs, education, social policy, and economic planning, including agriculture and politics. The establishment of the Islam Hadhari Institute (IHI) at the National University of Malaysia (UKM) and the Institute of Advanced Islamic Studies (IAIS) in 2008 was part of this initiative. Despite facing criticism and obstacles, Islam Hadhari reflects a serious attempt and commitment by the ruling elites to introduce a moderationstyle approach into Malaysian society. Badawi's religio-political philosophy 
paved the way for another comprehensive moderate approach introduced by his successor Najib Abdul Razak.

The current prime minister has been taking the concept of wasatizyah further by fusing it with the country's philosophy of "1Malaysia," which emphasizes the "importance of national unity regardless of race, background or religious belief," 13 to developing and strengthening society. In fact, 1Malaysia became the state philosophy in "the aftermath of March 2008 election and vote swings that were indicative of greater polarization and more pronounced lines of division among the ethnic and religious groups of Malaysia"14 in an attempt to bridge the gap between ethnic divisions and maintain the country's social cohesion and political stability. In addition, on September 27, 2010, Najib informed the United Nations General Assembly that "Malaysia stands at the geographical cross roads of major civilizations and religions of the world, [and] we seek to celebrate our multi-ethnic and multi-religious society for strategic strength and harmony." 15

Implicit in his speech, Najib stressed the need for an approach based on moderation, one predicated upon accepting diversity and mutual respectability without sacrificing Islamic values and identity. This position is consistent with the Qur'anic principle of calling upon Muslims to respect other religions $(\mathrm{Q}$. 109:6) and not to force others to accept Islam (Q. 2:256). This has become, as he clarified, the basis of Malaysia's approach to moderation.

Although Islam is the official religion, we honor other religions such as Buddhism, Christianity and Hinduism by making their religious and cultural celebration as national holidays ... It is this equilibrium that leads to moderation or wasatizyah in the Islamic tradition of mutual justice. ${ }^{16}$

Najib's administration has established three other institutions: the Global Movement of the Moderates Foundation (GMMF), ${ }^{17}$ the Institute of Wasatîyah Malaysia under the Prime Minister's Department (IWM-PMD), ${ }^{18}$ and the research-based International Institute of Wasatịyah under the International Islamic University Malaysia (IIW-IIUM). ${ }^{19}$ All of them have become platforms for promoting wasatizyah both at home and abroad.

The GMMF explains its raison d'être as "a new approach in international relations and foreign policy, with the main goal of applying perspectives and frameworks of moderation to realize world peace and harmony." The prime minister articulated the idea of establishing the GMMF in 2010 during his speech at the United Nations General Assembly (UNGA). For him, the "real divide is not between Muslims and non-Muslims or between the developed and developing worlds. It is between moderates and extremists. ${ }^{\circ 20}$ In 2013, Najib made the same plea at the UNGA by calling upon moderates from all religions, traditions, and nations to reclaim the center-stage from the encroach- 
ment of extremist elements. He insisted that "at the international level, moderation can guide our approach to the great global challenges of our age; violent extremism, sustainable development and equitable growth." ${ }^{21}$ Malaysia's approach has been well accepted by the international community. ${ }^{22}$

The IWM-PMD, established on January 17, 2012, attempts to promote moderation and harmony via close engagement with Muslim professionals, community leaders, scholars, students, non-governmental organizations, and the general public. As an input provider to wasatizyah, it is involved with national research, publication, public lectures, seminars, and conferences at both the national and international level, mainly in the Malay language. The institute, chaired by former minister Abdullah Md. Zin, is one of the country's most active institutes in terms of promoting and providing counter-narratives to extremism, terrorism, and all religious deviationist trends. ${ }^{23}$

The IIW, which has been affiliated with the IIUM, promotes academic research and publications on wasatizyah. Established on November 16, 2012 as a "non-partisan institute, which aims at fostering and enhancing moderation among members of the Muslim Ummah," it envisions itself as "a leading and respected intellectual center, which promotes and fosters moderation of the Muslim Ummah." In order to achieve this, the IIW's vision is to

Create awareness on the importance and necessity of wasatīyah in restoring the leading, dynamic and progressive roles of the Muslim Ummah; to establish linkages and networking among all sectors of the Muslim community, especially the younger generation; to undertake objective studies on the causes of Muslim disunity and conflicts in the world; and, to present tangible models of Muslim moderation which transcend ethnic, linguistic, cultural and geographical barriers. ${ }^{24}$

Barely three years old, the IIW is actively involved in a variety of postgraduate undertakings, such as research and studies, training, workshops, forums, seminars, conferences, publications, and dialogue. ${ }^{25}$ In its capacity as an independent research institute, it not only focuses on domestic issues but also serves as a platform for international researchers to carry out studies on projects concerning the ummah. It should be noted, however, that despite operating autonomously due to their different orientations, each institution does, in fact, support each other in order to create the wave of moderation and public awareness and serve as the domestic input providers for academic institutions as well as policymakers.

In facing the challenge of terrorism and the current threat of the "Islamic State" (IS) in Malaysia, the wasatīyah approach has become an even more relevant and needed instrument for providing counter-narratives to the extreme views and positions taken by the possible IS group in the country. In addition 
to using media outlets and public lectures to rectify any possible misunderstanding on Islam and jihad, Kuala Lumpur has developed its own rehabilitation program for militant detainees who have recently been arrested on terrorism-related charges. Special modules and syllabi are being developed in cooperation with academics, religious scholars, and law enforcement agencies - particularly the Royal Malaysia Police, Counter-Terrorism Division - to incorporate this approach as one of its key elements. This rehabilitation program, which has been operating since 2005, has proven to be quite successful.

Presently, the specter of IS looms large in and has already transcended the Middle East, so that it now, allegedly, reaches London, Paris, Ottawa, Copenhagen, and other western cities. Considering the gravity of the situation, President Barack Obama invited world leaders and international figures and organizations to a White House Summit on "Countering Violent Extremism," held on February 18-19, 2015, to develop strategies to fight the Islamic State's ideology and advances, especially its extremist narratives. As one of the individuals invited to attend this event, I presented Malaysian's experience and programs in countering mainly extremist religious ideologies. My presentation stressed the fact that advocacy and application of Malaysia's wasatiyah methods represent one of the key successes in dealing with its own home-grown violent extremism.

In conclusion, Malaysia's wasatīyah approach grew out of its unique Islamic tradition and inherited form of Malay culture. The country has proven that it can provide possible solutions to modern challenges while simultaneously maintaining the spirit of the ummah in terms of promoting a healthy lifestyle and mutual coexistence.

\section{Endnotes}

1. Muhammad Hashim Kamali, Moderation and Balance in Islam: The Qur'anic Principle of Wasatiyyah (Kuala Lumpur: Ilmiah Publishers, 2010), 1.

2. See Yusuf al-Qardaawi, Fiqh al-Jihād (Cairo: Maktabah al-Wahbah, 2009).

3. See Harry R. Lewis, Excellence without A Soul: Does Liberal Education Have a Future? (Philadelphia: Perseus Books Group, 2006).

4. See Alan Greenspan, The Age of Turbulence: Adventures in A New World (London: Penguin Books, 2007).

5. See Mohamed ElBaradei, Age of Deception: Nuclear Diplomacy in Treacherous Times (New York: Metropolitan Books, 2011).

6. See Réne Guenon, The Reign of Quantity and the Signs of the Times (Baltimore: Penguin Books, 1945).

7. See Seyyed Hossain Nasr, Man and Nature: The Spiritual Crisis in Modern Man (London: Unwin Hyman, 1968); Seyyed Hossain Nasr, Islam and Plight of Modern Man (London: Islamic Texts Society, 2002). 
8. Ahmad F. Yousif, Religious Freedom Minorities and Islam: An Inquiry into the Malaysian Experience (Kuala Lumpur: IIUM Press, 2011), 160.

9. See Ahmad Sarji, Malaysia's Vision 2020: Understanding Concepts, Implications, and Challenges (Kuala Lumpur: Pelanduk Publications, 1993).

10. Hussin Mutalib, Islam and Ethnicity in Malay Politics (Singapore: Oxford University Press, 1990), 144.

11. Abdullah Ahmad Badawi, Islam Hadhari: A Model Approach for Development and Progress (Kuala Lumpur: MPH Group Publishing, 2006), 58-59.

12. Abdullah Ahmad Badawi, Pembangunan Model Insan: Human Capital Development (Kuala Lumpur: Institut Pentadbiran Awam Negara (INTAN), 2006), 143.

13. For the detailed explanation on this concept, see: http://www.1malaysia.com.my/ en/the-story-of-1malaysia (accessed 20 March 2012).

14. Muhammad Hashim Kamali, Moderation and Balance in Islam, 44.

15. See Najib's speech at the United Nations General Assembly (UNGA), accessible at http://najibrazak.com/en/blog/speech-at-the-69th-un-general-assembly/ (accessed on 20 March 2015).

16. See Najib's speech at the United Nations General Assembly (UNGA) the 65th Sessions at http://www.najibrazak.com/en/speeches/the-65th-session-of-theunited-nations-general-assembly/ (accessed on 20 March 2015).

17. The Global Movement of the Moderates Foundation was established in April 2012 to meet the aspirations proposed by Prime Minister Razak, who is also its patron-founder. Its headquarters is located on the fifteenth floor of Menara Manulife, No. 6, Jalan Gelenggang, Damansara Heights, 50490 Kuala Lumpur.

18. The Institute of Wasatiyyah, Prime Minister's Department, was established on December 3, 2012, and is governed by the Board of Trustees headed by Prime Minister Razak and seven other members. Its main office is located at Jabatan Perdana Menteri, Aras 4, Blok B1, Kompleks B, Pusat Pentadbiran Kerajaan Persekutuan, 62692 Putrajaya.

19. The International Institute of Wasatiyyah-IIUM was established on November 16, 2012, under the International Islamic University Malaysia. This researchbased institute is directly under the rector's office at IIUM. IIW maintains its headquarters at IIUM Kuala Lumpur Campus, No. 26, Persiaran Duta, Taman Duta, 50480 Kuala Lumpur.

20. See the Global Movement of the Moderates's website: http://www.gmomf.org/ about-us/introduction-on-gmmf/ (accessible on 20 March 2015).

21. Ibid.

22. Aziz Jamaluddin Mhd. Tahir, "Institut Wasatiyyah tolak ekstrimisme," Utusan Malaysia, 20 January 2012.

23. Ibid.

24. See the IIW-IIUM website for detailed information at http://www.iium.edu.my/ wasatiyyah (accessible on 20 March 2015).

25. Ibid. 